\title{
DHT-receptor in cultured human fibroblasts: binding study in a family with androgen insensitivity (complete testicular feminisation)
}

\author{
E DONTI,* I NICOLETTI, $\dagger$ P FILIPPONI, $\dagger$ G VENTI,* V BOCCHINI,* \\ AND F SANTEUSANIO $\dagger$ \\ From*the Istituto di Biologia Generale and †the Istituto di Clinica Medica, Università di Perugia, 06100 \\ Perugia, Italy
}

SUMMARY $\quad{ }^{3} \mathrm{H}$-DHT binding was examined in cultured skin fibroblasts from a patient with complete testicular feminisation (CTF), from his heterozygote mother, and his clinically normal sister, who menstruated normally. Binding parameters were: $B_{\max }<1 \mathrm{fmol} / \mathrm{mg}$ protein and $\mathrm{K}_{\mathbf{D}}$ unmeasurable in CTF $; B_{\max }=24 \mathrm{fmol} / \mathrm{mg}$ protein and $K_{D}=3 \cdot 63 \times 10^{-9} \mathrm{~mol} / 1$ in the mother; and $B_{\max }=46 \mathrm{fmol} / \mathrm{mg}$ protein and $K_{D}=3 \cdot 7 \times 10^{-9} \mathrm{~mol} / 1$ in the sister. Five cultures obtained from genital and non-genital skin of normal male and female subjects were used as controls, in which $\mathbf{B}_{\max }$ ranged from 37 to $62 \mathrm{fmol} / \mathrm{mg}$ and $\mathrm{K}_{\mathrm{D}}$ from $2 \cdot 0$ to $3 \cdot 6 \times 10^{-9} \mathrm{~mol} / 1$.

The considerable reduction of $B_{\max }$ in the obligate heterozygote and the normal binding capacity in the sister, a probable heterozygote, suggests that it may be possible to use the DHT-receptor assay to identify carriers in families with androgen resistance.

Dihydrotestosterone, the $5 \alpha$ reduced form of testosterone, interacts with specific cytosol receptors in cultured human fibroblasts from normal male and female subjects. ${ }^{12}$

The DHT-receptor protein is absent in most patients with CTF. ${ }^{13-5}$ It is believed that the synthesis of this protein is controlled by an $\mathrm{X}$ linked gene and it seems that such a gene locus is subject to inactivation, like other $\mathrm{X}$ linked loci. ${ }^{6}$ It remains to be clarified whether the lyonisation influences the phenotypic expression of the gene to a certain extent so that there is no discrimination between normal subjects and carriers. To this end we compared the binding capacity of cultured skin fibroblasts from an 18-year-old possible heterozygote (fig 1, IV.1), the sister of a CTF patient, with that of the 22-yearold hemizygote (IV.2), the 46-year-old obligate heterozygote mother (III.3), and a group of normal control subjects all at reproductive age.

In this way the presence of a distinct difference in $B_{\max }$ between the two female subjects of the same family examined by us was shown.

\section{Materials and methods}

Radioactive labelled steroid $1,2(\mathrm{n})^{3} \mathrm{H}$-5 $\alpha$-dihydrotestosterone (specific activity $66 \mathrm{Ci} / \mathrm{mmol}$ ) was ob- tained from Amersham (England). Unlabelled steroid ( $5 \alpha$-dihydrotestosterone), purchased from Sigma (USA), was recrystallised from the organic solvent before the assay. The grades of the reagents, tissue culture media, and other chemicals used were the best available from commercial sources.

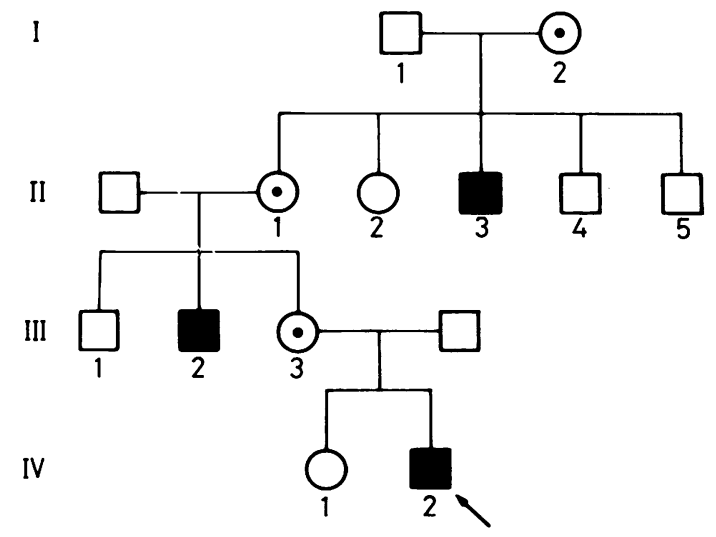

Androgen insensitivity

- Heterozygote

FIG 1 Pedigree of family with androgen insensitivity. 


\section{CELL CULTURES}

The origins of the cell cultures examined are shown in the table. Cell cultures from the CTF patient (C106, C107) were obtained from abdominal skin and testicular tissue, taken during gonadectomy. The cell cultures from his sister (C113) and mother (C114) were obtained from the skin of the forearm. The control cultures were derived as follows: $\mathrm{C} 120$ from the abdominal skin of a normal female; C116, C118, C119 from the skin of the forearm of three normal males; C112 from scrotal skin from one normal male.

Fibroblast cultures were propagated in Eagle's MEM supplemented with $20 \%$ fetal calf serum (FCS), vitamins, L-glutamine, and non-essential amino-acids in closed glass flasks, each having a surface area about $44 \mathrm{sq} \mathrm{cm}$, at $37^{\circ} \mathrm{C}$. All the assays were performed between the 6 th and 13 th subcultures

\section{DHT-RECEPTOR ASSAY}

DHT-receptor assay was performed according to Kaufman et al. ${ }^{7}$ Confluent monolayers of fibroblasts were washed with fresh Eagle's MEM and reincubated with FCS-free medium for 24 hours. Then the MEM was removed and the monolayers were washed twice with $2 \mathrm{ml}$ of FCS-free medium. The monolayers were incubated in duplicate with various concentrations ( 1 to $10 \mathrm{mmol} / \mathrm{l})$ of ${ }^{3} \mathrm{H}-\mathrm{DHT}$ in FCS-free MEM, with or without addition of $0.5 \mu \mathrm{mol} / 1$ unlabelled DHT, for 45 minutes at $37^{\circ} \mathrm{C}$.

The medium was removed and the molarity of labelled DHT was controlled by measuring the radioactivity of an aliquot. The cells were washed twice with MEM, harvested by $0.25 \%$ trypsin, and washed twice in $5 \mathrm{ml}$ ice-cold buffer $(0.02 \mathrm{~mol} / \mathrm{l}$ Tris- $\mathrm{HCl}, \mathrm{pH} 7 \cdot 5,0.32 \mathrm{~mol} / 1$ sucrose, $1 \mathrm{~g} / 1$ bovine gammaglobulin) by centrifugation at $200 \mathrm{~g}$ for 10

TABLE Binding parameters of DHT-receptor and origin of cell cultures

\begin{tabular}{|c|c|c|c|}
\hline $\begin{array}{l}\text { Cell } \\
\text { culture }\end{array}$ & Origin & $\begin{array}{l}K_{D}\left(\times 10^{-9}\right. \\
m o l / l)\end{array}$ & $\begin{array}{l}B_{\max }(\mathrm{fmol} / \mathrm{mg} \\
\text { protein) }\end{array}$ \\
\hline C106 & $\begin{array}{l}\text { Abdominal skin of CTF } \\
\text { patient }\end{array}$ & Unmeasurable & $<1$ \\
\hline $\mathrm{Cl07}$ & $\begin{array}{l}\text { Gonadal tissue of CTF } \\
\text { patient }\end{array}$ & Unmeasurable & $<1$ \\
\hline C113 & Forearm skin of sister & $3 \cdot 7$ & 46 \\
\hline C114 & Forearm skin of mother & $3 \cdot 6$ & 24 \\
\hline $\mathrm{C} 116$ & $\begin{array}{l}\text { Forearm skin of normal } \\
\text { male }\end{array}$ & $3 \cdot 6$ & 44 \\
\hline C118 & $\begin{array}{l}\text { Forearm skin of normal } \\
\text { male }\end{array}$ & $2 \cdot 2$ & 46 \\
\hline $\mathrm{C} 119$ & $\begin{array}{l}\text { Forearm skin of normal } \\
\text { male }\end{array}$ & $3 \cdot 2$ & 45 \\
\hline $\mathrm{C} 120$ & $\begin{array}{l}\text { Abdominal skin of } \\
\text { normal female }\end{array}$ & $2 \cdot 7$ & 37 \\
\hline $\mathrm{C} 112$ & $\begin{array}{l}\text { Genital skin of normal } \\
\text { male }\end{array}$ & $2 \cdot 0$ & 62 \\
\hline
\end{tabular}

minutes at $4^{\circ} \mathrm{C}$. All subsequent steps were performed at $4{ }^{\circ} \mathrm{C}$. The pellets were lysed in $0.5 \mathrm{ml} 0.02 \mathrm{~mol} / 1$ Tris- $\mathrm{HCl}, \mathrm{pH} 7 \cdot 5,0.4 \mathrm{~mol} / 1 \mathrm{KCl}, 1.5 \mathrm{mmol} / 1$ EDTA, and $2 \mathrm{mmol} / \mathrm{l}$ mercaptoethanol by an ultrasonic cleaner. After centrifugation for 20 minutes at $2000 \mathrm{~g}$, the supernatants were removed and unbound steroid adsorbed with charcoal-dextran $\Omega$ (pellets were previously prepared by centrifugation at $2000 \mathrm{~g}$ for 15 minutes of a mixture of $1 \%$ charcoal $\vec{\circ}$ and $0.1 \%$ dextran $\mathrm{T}-70$ in Tris- $\mathrm{KCl}, \mathrm{pH} 7 \cdot 5$, buffer).
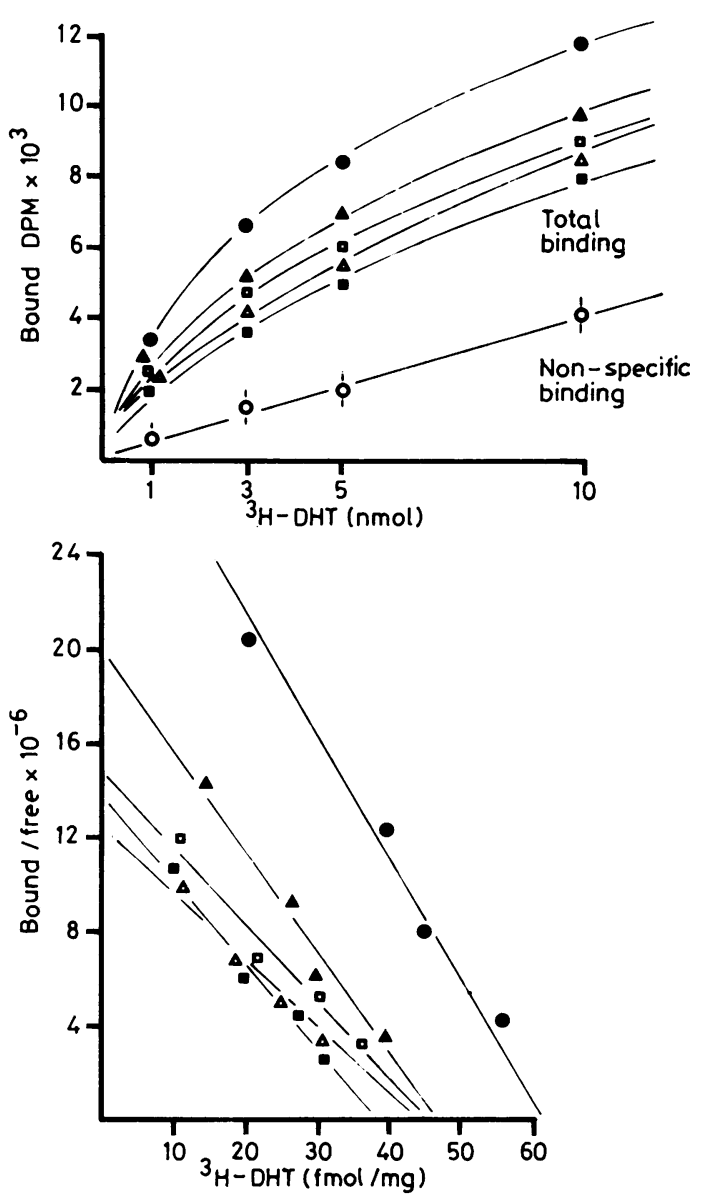

FIG 2 DHT-receptor kinetics and Scatchard plot analysis of cultures obtained from normal subjects. Total binding is $\mathrm{dpm} / \mathrm{mg}$ protein bound in the presence of ${ }^{3} \mathrm{H}$-DHT alone; non-specific binding is $\mathrm{dpm} / \mathrm{mg}$ protein in the presence of ${ }^{3} \mathrm{H}-\mathrm{DHT}$ and a 1000-fold excess of unlabelled DHT. The abscissa of Scatchard plots represents ${ }^{3} \mathrm{H}-\mathrm{DHT}$ specifically bound, the ordinate moles bound divided by concentration of free hormone. $K_{D}$ is the reciprocal of the slope of the Scatchard plot. 
The cytosol-charcoal mixture was vortexed, incubated for 15 minutes, and centrifuged at $2000 \mathrm{~g}$ for 20 minutes. Portions of the supernatant were removed for protein determination ${ }^{8}$ and for radioactivity counting. For this purpose $150 \mu$ l aliquots in $5 \mathrm{ml}$ of Insta-gel (Packard, USA) were counted in a Tricarb (Packard, USA) scintillation spectrometer. Counting efficiency ranged from 33 to $38 \%,{ }^{3} \mathrm{H}-$ toluol serving as internal standard. The amount of specifically bound ${ }^{3} \mathrm{H}$-DHT was determined as the difference between the radioactivity bound in cell cultures containing a great excess of unlabelled DHT

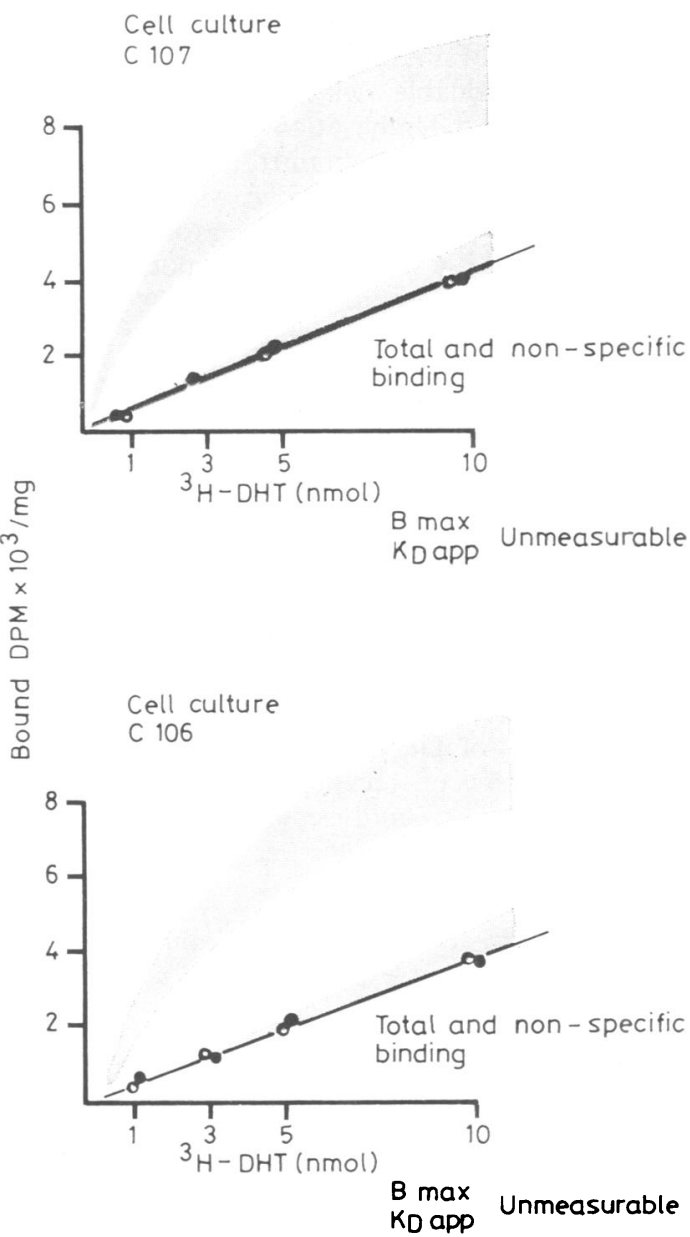

FIG 3 Binding curves of cultured fibroblasts derived from inguinal skin (C107) and gonadal tissue (C106) of the proband compared to binding curves (mean $\pm S D$ ) of normal subjects (shaded area). The absence of specifically bound ${ }^{3} \mathrm{H}-\mathrm{DHT}$ does not permit Scatchard's analysis. and parallel cultures containing ${ }^{3} \mathrm{H}-\mathrm{DHT}$ alone. The binding capacity $\left(\mathrm{B}_{\max }\right)$ and apparent dissociation constant $\left(\mathrm{K}_{\mathbf{D}}\right)$ were determined according to Scatchard. ${ }^{9}$

\section{Results}

The dissociation constants $\left(K_{D}\right)$ of the hormone receptor complex and the values for the maximal binding capacities $\left(\mathbf{B}_{\max }\right)$ in the cell cultures examined are listed in the table.

The cultures derived from forearm and abdominal skin of normal subjects showed a low capacity, high affinity ${ }^{3} \mathrm{H}$-DHT binding, as shown in the binding curves and Scatchard's plot analysis (fig 2). The $\mathbf{B}_{\max }$ and $\mathbf{K}_{\mathbf{D}}$ values were similar in the cultures derived from non-genital skin, ranging respectively from 37.1 to $46.0 \mathrm{fmol} / \mathrm{mg}$ protein and from $2 \cdot 2$ to $3.6 \times 10^{9} \mathrm{~mol} / \mathrm{l}$. The non-specific binding showed no significant variation between cultures, correlating linearly with the concentration of ${ }^{3} \mathrm{H}$-DHT in the medium. The culture derived from genital (scrotal) skin showed a greater binding capacity $(62 \mathrm{fmol} / \mathrm{mg}$
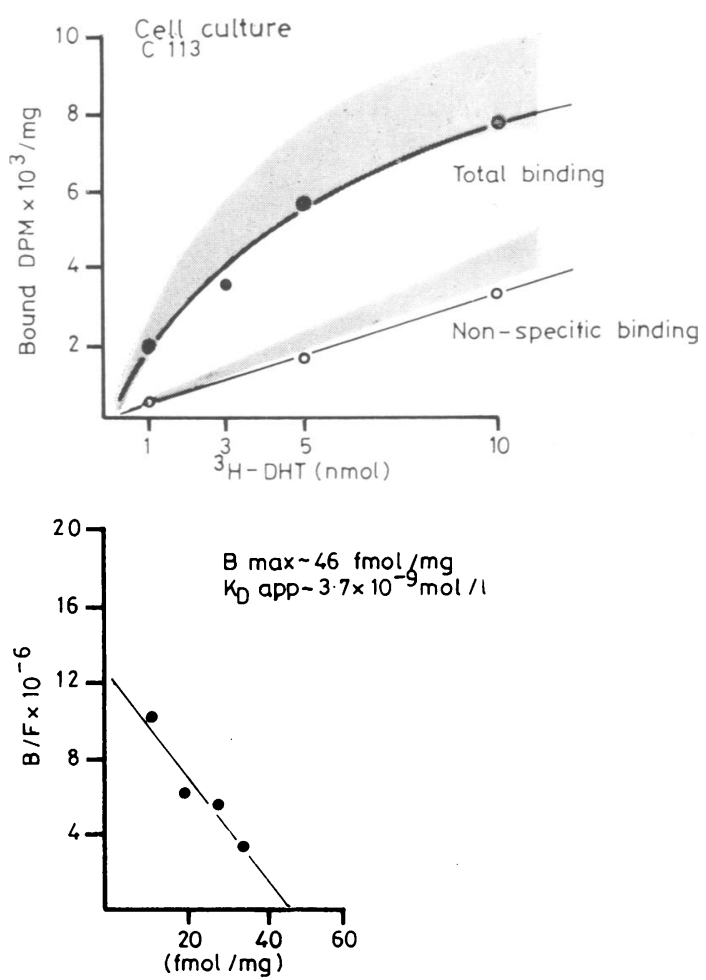

FIG 4 Binding curve and Scatchard's analysis of cultures derived from sister's skin. 

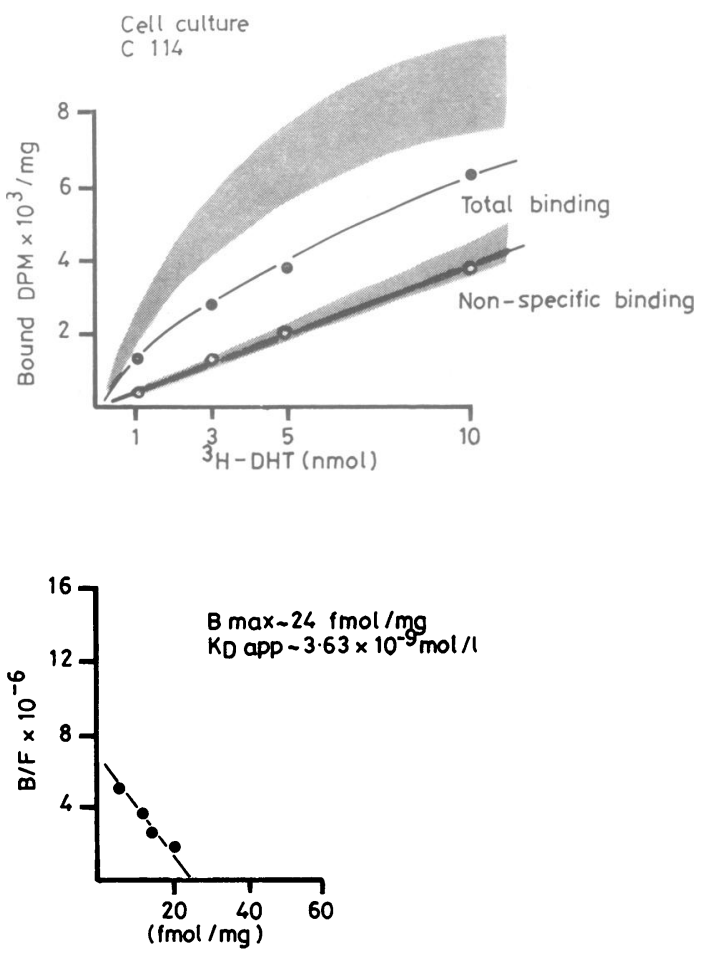

FIG 5 Binding curve and Scatchard's analysis of cultures derived from mother's skin.

protein) compared with those derived from abdominal or forearm skin (fig 2).

No appreciable DHT binding was detectable in skin or gonadal fibroblasts from the androgen insensitive patient (fig 3). The binding parameters of culture $\mathrm{C113}$, derived from the patient's sister, were within the normal range (fig 4). The fibroblasts obtained from the mother's skin (C114) showed a significant reduction of binding capacity $(24.8$ vs $43 \mathrm{fmol} / \mathrm{mg}$, mean $\pm 7.33 \mathrm{SD}$ of controls), even though the affinity of the ${ }^{3} \mathrm{H}-\mathrm{DHT}$ receptor complex was normal (fig 5).

\section{Discussion}

Complete testicular feminisation is a genetic disorder caused by mutation of an X linked gene. ${ }^{6} 10$ The corresponding phenotype is characterised by the absence of androgen receptors, leading to feminine differentiation of androgen target organs. The lack oi cytosol receptor protein, responsible for the tr unsport of DHT into the nucleus, can be shown in cultured skin fibroblasts derived from CTF patients. $^{111} 12$
The cultures derived from normal subjects showed a low capacity, high affinity ${ }^{3} \mathrm{H}-\mathrm{DHT}$ binding.

Data obtained from different laboratories show considerable variation in $\mathbf{B}_{\max }$ values in normal subjects. ${ }^{35713}$ In our controls, however, the binding capacity ranged from 37 to $47 \mathrm{fmol} / \mathrm{mg}$ protein in cultures derived from non-genital skin and reached $62 \mathrm{fmol} / \mathrm{mg}$ in a culture derived from scrotal skin. Whether the reduced dispersion of the $B_{\max }$ values in our controls can be attributed to the small number of subjects examined or to the high viability of cell cultures in which the DHT-receptor assay was performed remains to be ascertained.

DHT was undetectable in cultures derived from the skin and testicular tissue of the patient with the complete form of androgen insensitivity and this is, therefore, classifiable within complete receptor negative testicular feminisation. ${ }^{5}$

The $\mathbf{B}_{\max }$ of cultures obtained from the mother's skin was reduced in comparison with the controls (24 vs 43), even though DHT-receptor affinity was normal $\left(K_{D}=3.6 \times 10^{-9}\right)$. The reduced binding capacity of the maternal fibroblasts is in agreement with the hypothesis of inactivation of the $X$ linked locus controlling DHT-receptor synthesis in obligate heterozygotes. ${ }^{6}$ In the phenotypically normal sister, binding and affinity values were within the normal range. This difference could be explained by the fact that the sister was not a carrier; this hypothesis should, however, be considered with caution. Randomised inactivation of $X$ linked genes, according to Lyon's hypothesis, ${ }^{14}$ makes it difficult to interpret data in $\mathrm{X}$ linked diseases.

At present, a definite conclusion cannot be drawn from our observations. However, we believe that further studies of DHT binding parameters in the female members of receptor negative, androgen insensitive families could be useful for the identification of the heterozygote.

The authors wish to thank C Giammartino and F Pimpinelli for their expert technical assistance.

\section{References}

1 Keenan BS, Meyer WJ III, Hadjian AJ, Jones HW, Migeon CJ. Syndrome of androgen insensitivity in man: absence of $5 \alpha$-dihydrotestosterone binding protein in skin fibroblasts. J Clin Endocrinol Metab 1974;38:1143-6.

2 Keenan BS, Meyer WJ III, Hadjian AJ, Migeon CJ. Androgen receptor in human skin fibroblasts. Characterisation of a specific $17 \beta$-hydroxy-5 $\alpha$ androstan-3-oneprotein complex in cell sonicates and nuclei. Steroids 1975;25:535-52.

3 Amrhein JA, Meyer WJ, Jones HW, Migeon CJ. Androgen insensitivity in man: evidence for genetic heterogeneity. Proc Natl Acad Sci USA 1976;73:891-4. 
4 Kaufman M, Straisfeld C, Pinsky L. Male pseudohermaphroditism presumably due to target organ unresponsiveness to androgen. Deficient $5 \alpha$-dihydrotestosterone binding in cultured fibroblasts. $J$ Clin Invest 1976;58:345-50.

5 Griffin JE, Wilson JD. The syndromes of androgen resistance. $N$ Engl J Med 1980;302:198-209.

6 Meyer WJ III, Migeon BR, Migeon CJ. Locus on human $\mathrm{X}$ chromosome for dihydrotestosterone receptor and androgen insensitivity. Proc Natl Acad Sci USA 1975; 72:1469-72.

7 Kaufman M, Straisfeld C, Pinsky L. Specific $5 \alpha$-dihydrotestosterone binding in labial skin fibroblasts cultured from patients with male pseudohermaphroditism. Clin Genet 1976;9:567-74.

${ }^{8}$ Lowry ON, Rosebrough N, Farr A, Randall R. Protein measurement with the Folin phenol reagent. J Biol Chem $1961 ; 193: 265-75$.

9 Scatchard G. The attractions of proteins for small molecules and ions. Ann NY Acad Sci 1949;51:660-72.

10 Wilson JD, MacDonald P. Male pseudohermaphroditism due to androgen resistance: testicular feminization and related syndromes. In: Stanbury JB, Wyngaarden JB, Fredrickson DS, eds. The metabolic basis of inherited disease. 4th ed. New York: McGraw-Hill, 1978.

11 Griffin JE, Punyashthiti K, Wilson JD. Dihydrotestosterone binding by cultured human fibroblasts. Comparison of cells from control subjects and from patients with hereditary male pseudohermaphroditism due to androgen resistance. J Clin Invest 1976;57:1342-51.

12 Bauknecht T. Studies on steroid hormone receptcrs $(5 \alpha-$ dihydrotestosterone, estradiol, and dexamethasone) in cultured human fibroblasts and amniotic fluid cells. Hum Genet 1977;39:321-8.

13 Herfert J, Wienker TF, Ropers HH. The presence of androgen-binding receptors in genital and nongenital skin fibroblasts. Hum Genet 1980;53:271-3.

14 Lyon MF. X-chromosome inactivation and developmental patterns in mammals. Biol Rev 1972;47:1-35.

Requests for reprints to Dr Emilio Donti, Istituto di Biologia Generale, Università di Perugia, Via del Giochetto, 06100 Perugia, Italy. 